POLITEJA

nr 1(58), 2019, s. 47-63

https://doi.org/10.12797/Politeja.16.2019.58.04

\author{
Aleksandra GRUSZCZYK \\ Uniwersytet Jagielloński \\ aleksandra.gruszczyk@gmail.com
}

\title{
THÉMIS JAKO KATEGORIA GRANICZNA
}

\section{ABSTRACT Thémis as a Liminal Category}

Thémis is a concept deeply rooted in the culture of ancient Greece. As a category delineating the limits of "what's right" as well as a personification of this very concept in Themis, the Titaness ruling the sphere of eternal order, justice, laws and mores in the Greek religion, thémis in ancient Greece was the ultimate boundary of the social reality. Situated on the crossroads between two spheres: the sacrum and the profane, this concept also served as the foundation of an impassable axio-normative barrier between that which is human and which is other-than-human: either god-like or beast-like. Thémis as a philosophical and axio-normative notion still remains a valid scientific category, which can be successfully used in the explication and analysis of the processes of emergence and transformation of contemporary social and individual boundaries. The examination of the socio-cultural aspects of themis facilitates the analysis of the communal factors influencing the individual world-views, as well as those forming the limits and content of the prevailing ethics.

Key words: thémis, liminality, war, PTSD, morality/ethics

Słowa kluczowe: thémis, graniczność, wojna, PTSD, moralność/etyka 
Thémis ( $\Theta \varepsilon \mu l \varsigma)$, siostra Kronosa - Czasu, i Mnemosyne - Pamięci, pierwsza żona oraz doradczyni Zeusa, była w greckiej mitologii boginią etyki, prawa, sprawiedliwości i porządku. Miarą znaczenia Temidy było jej miejsce w kosmogonii, mitycznej genealogii greckiego świata: Thémis była Tytanidą, jedną z dwanaściorga dzieci Uranosa i Gai, czyli Nieba i Ziemi. Innymi słowy, Thémis narodziła się w wyniku pierwszego podziału świata - jak również jego dążenia do ponownego zjednoczenia. Fakt fizycznego i metaforycznego starszeństwa Temidy wobec olimpijskich bogów podkreślał nie tylko chronologię powstania reprezentowanych przez nią wartości, ale zarazem ich istotność w codziennym życiu Greków. Po wojnie bogów z tytanami Thémis jako jedyna Tytanida pozostała na Olimpie, ciesząc się szacunkiem i uznaniem zarówno nieśmiertelnych, jak i ludzi. W roli doradczyni Zeusa Temida wpływała na jego ostateczne wyroki, zażegnywała spory między bogami oraz cywilizowała zasady działania olimpijskiego życia społecznego. Thémis bowiem, czuwając nad przestrzeganiem naturalnego, niezmiennego porządku świata społecznego, patronowała jednocześnie wszystkim zgromadzeniom wspólnoty: zarówno tym o funkcjach prawodawczych, takich jak rady czy sądy, jak i tym o funkcjach czysto socjalnych, przede wszystkim ucztom. Jako że bogowie w greckiej mitologii nierzadko upostaciowali to, czemu patronowali, kategoria thémis w kulturze greckiej oznaczała boskie prawo, wieczne i niezmienne, obdarzone sankcją tradycji, zwyczaju i rytuału - a także religii.

Społeczne i kulturowe znaczenie Temidy w ograniczonej formie przetrwało w kręgu cywilizacji zachodniej do dziś - współcześnie wpływy greckiej bogini zostały znacząco okrojone, ale nadal pozostaje ona patronką sądów, sprawiedliwości oraz prawa jako powszechnie akceptowanego systemu wyznaczającego zasady działania wspólnoty. Przedstawiana najczęściej w postaci kobiety z zawiązanymi oczami, z wagą w jednej i mieczem w drugiej ręce, Thémis uosabia bezstronność i sprawiedliwość wyroku oraz umiejętność oddzielania prawdy od fałszu. Jej postać, górująca nad wieloma budynkami sądowymi w kręgu kultury zachodniej, a nawet poza jego granicami, stanowi również wyraziste symboliczne przypomnienie nieuchronności i surowości sankcji grożących za złamanie chronionych przez nią praw.

\section{GRANICE THÉMIS}

Granice thémis jako boskiej sankcji często określane były poprzez przeciwstawienie jej kategorii nomoi - praw czysto ludzkich ${ }^{1}$. Najdoskonalszą analizą tego dylematu w literaturze pozostaje niezmiennie Antygona. Dramat Sofoklesa ogniskuje się na konflikcie moralnym, w którym prawa ludzkie, reprezentowane przez Kreona, zaprzeczają prawom boskim, których wyznawczynią, nawet za cenę śmierci, pozostaje tytułowa córka

Nomos, Dike i inne bóstwa upostaciowujące różne formy ludzkiego prawa są w greckiej kulturze i religii przedstawiane jako późniejsze i zazwyczaj pochodzące od Thémis lub Zeusa. Dla uproszczenia $\mathrm{w}$ artykule stosuję wyłącznie kategorię nomoi, mimo powyższych zastrzeżeń dotyczących jej niejednoznaczności oraz późniejszego powstania. Patrz m.in. Hezjod, Teogonia, przeł. K. Kaszewski, Warszawa 2005, oraz Ajschylos, Agamemnon, przeł. H.W. Smyth, Cambridge 1926. 
Edypa $^{2}$. Kreon mógł wprowadzić swoje prawo i wyegzekwować jego przestrzeganie, jednak sprzeniewierzenie się boskim edyktom w dłuższej perspektywie nieodmiennie kończyło się tragedią buntowników - historia rodu Labdakidów jest wszak tylko jedną $\mathrm{z}$ wielu podobnych lekcji greckiej mitologii.

Rysunek 1. Zeus w towarzystwie Temidy, Hermesa i Ateny

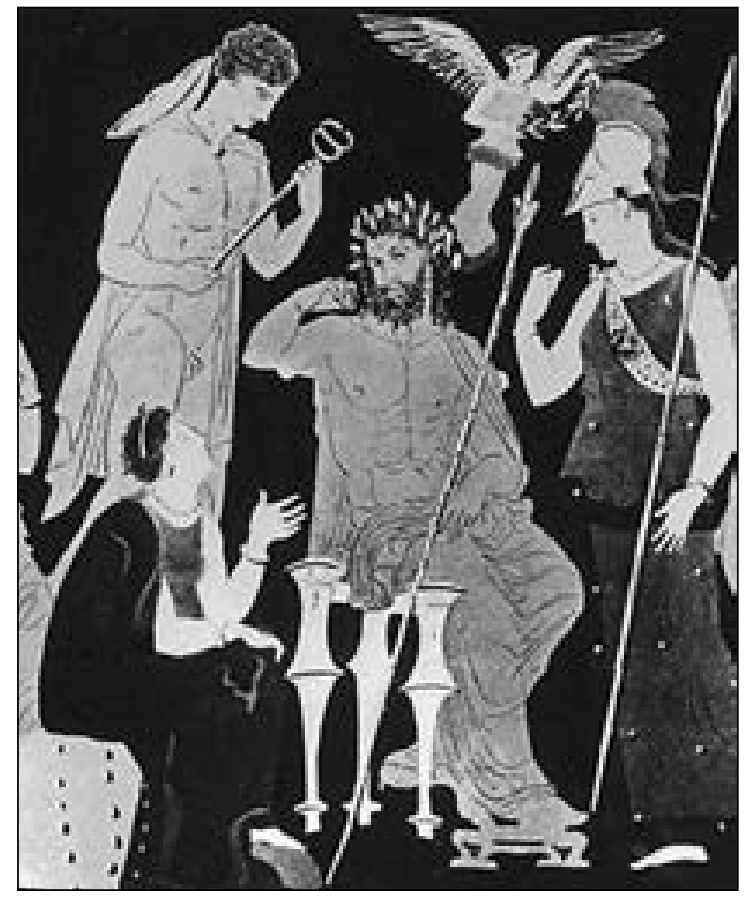

Źródło: @ Harvard Art Museums

Uzupełnianie się i wzajemna sprzeczność praw boskich i ludzkich wyraźnie widoczne są również w greckim podejściu do obcego. Obcy - Inny, barbarzyńca - był nieznany i groźny właśnie poprzez swój brak znajomości zasad, praw czy nawet języka używanego w danej społeczności. Obcy nie podlegał kontroli grupy, do której wchodził, nie stosował się do obowiązujących w niej sankcji, co tworzyło podwójne wykluczenie: nie znał prawa, ale i prawo nie uznawało jego. Tym niemniej obcy był przede wszystkim gościem: i jako gość nawet obcy podlegać musiał pewnym uniwersalnym, najbardziej podstawowym zasadom thémis, stworzonym na początku świata jeszcze przed powstaniem ludzi czy bogów. Podległość każdego, nawet obcego, wobec thémis była dla Greków oczywista i wynikała z jego prostej przynależności do rodzaju ludzkiego ${ }^{3}$.

2 W tym kontekście o thémis wspomina równieżJanusz Radwan-Pragłowski. Patrz:J.Radwan-Pragłowski, Kobieta i mężczyzna. Cztowiek rozdwojony, Kraków 2009.

3 Omawiany stosunek Greków do obcych, wyrażający się w pojęciu xenia, szczególnie wyraźnie widać w Odysei Homera, w której Odyseusz odwiedza kolejno wyspy Polifema, Kirke, Kalipso oraz utopijny 
Thémis bowiem oznacza przede wszystkim „to, co słuszne”, „to, co właściwe”. W ten sposób thémis nakreśla granicę między usankcjonowanym społecznie działaniem, znajdującym się w sferze społecznego porządku, a chaosem bez-prawia, $a$-moralności, gdzie każde zachowanie jest równie dozwolone i równie zabronione, ponieważ nie ma wartości, według których można by je ocenić. Thémis jest sankcją boską: fakt przestrzegania lub nieprzestrzegania boskiego prawa oceniany jest w kategoriach moralnych jako działanie obdarzone moralnymi konsekwencjami. Thémis jest również pierwszym porządkiem - pierwszą linią podziału wyłaniającego się z Chaosu świata, pojawiającą się wraz z Czasem (Kronosem), Świattem (Hyperionem) czy Pamięcią (Mnemosyne). Społeczny porządek, oddzielony od chaosu granicą prawa, wyznacza zatem również granice ludzkiej wspólnoty. To przekonanie wyraża się jednocześnie w mitycznym światopoglądzie starożytnych Greków: przypisanie Temidzie opieki nad ludzkimi zgromadzeniami jasno pokazuje jej funkcję spajającą, łączącą zarówno daną grupę społeczną, jak i całą wspólnotę ludzką. Thémis rozumiana jako „to, co słuszne” jest bowiem uniwersalną zasadą postępowania: leży u podstaw fenomenologicznego Lebenswelt ${ }^{4}$, społecznie podzielanego świata życia codziennego, niekwestionowanego poprzez swoją powszechność i oczywistość.

\section{THÉMIS W ANTROPOLOGII}

Kategorię thémis do współczesnych rozważań antropologicznych wprowadził Moses Finley - anglosaski znawca historii starożytnej, autor przełomowych dzieł, takich jak The Ancient Economy (1973) czy The World of Odysseus (1954, rev. 1978). Analizując świat przedstawiony przez Homera ${ }^{5}$, Finley zwrócił uwagę na znaczenie thémis. Jako kategoria etyczna wyznaczająca ramy tego, co właściwe, a zarazem kategoria absolutyzująca, określająca nieprzekraczalne ramy wspólnoty znaczeń i wartości, thémis niepodzielnie rządziła życiem starożytnych Greków, definiując kluczowe dla ówczesnych społeczności pojęcia honoru, powinności czy daru ${ }^{6}$. Złamanie thémis (choć nie nomoi) przez Agamemnona pod Troją prowadzi do tragedii Achillesa opisanej przez Homera w Iliadzie ${ }^{7}$. Spór o brankę wojenną między greckim przywódcą wojennym

kraj Feaków. Patrz: Homer, Odyseja, przeł. L. Siemieński, [online] https://wolnelektury.pl/katalog/ lektura/homer-odyseja.html, 9 I 2018.

4 Kategorii Lebenswelt używam tu w znaczeniu zaproponowanym przez Alfreda Schütza. A. Schütz, O wielości światów, przeł. B. Jabłońska, Kraków 2008.

5 Celowo pomijam tu dyskusję, czy Homer był jeden, czy dwóch, czy też cała grupa bardów (aojdów) występowała pod tym zbiorczym imieniem. Przyjmujęza większością ekspertów, że świat przedstawiony przez Homera, czyli ten opisany w Iliadzie i Odysei, to świat grecki po upadku cywilizacji mykeńskiej, pomiędzy IX a VII w. p.n.e.

6 M. Finley, The World of Odysseus, New York 2002.

7 Epos Homera zaczyna się od skierowanej do Muzy inwokacji, stanowiącej zarazem podsumowanie treści poematu: Gniew Achilla, bogini, gtoś, obfity w szkody..., cyt. za: Homer, Iliada, przeł. F.K. Dmochowski, [online] https://wolnelektury.pl/katalog/lektura/homer-iliada.html, 27 XI 2017. 
a największym herosem Greków zostaje rozwiązany przemocą, kiedy to Agamemnon ${ }^{8}$, łamiąc uświęcone zasady dotyczące podziału i własności łupów, odbiera Bryzeidę wodzowi Myrmidonów. To drastyczne naruszenie powszechnie uznawanych moralnych praw rządzących greckim życiem podważa oczywistość i intersubiektywność Lebensweltu Achillesa, co w konsekwencji prowadzi do jego alienacji. Pozbawiony zaufania i wiary w innych Achilles pielęgnuje w sobie poczucie niezasłużonej krzywdy. Przez długi czas odmawia udziału w wojnie, biernie obserwując klęski swoich współbraci, niewzruszony ich tragediami czy śmiercią. Jego dawni towarzysze nie należą już do kręgu wspólnoty Achillesa - stali się zdrajcami poprzez sam fakt bycia biernymi świadkami złamania thémis przez Agamemnona. W wyniku niechlubnego czynu wodza Achajów i późniejszego samowykluczenia Achilles de facto odmawia sobie statusu człowieka, odrzuca bowiem powszechny porządek społeczny i rządzące wspólnotą wartości. To pierwsze naruszenie thémis pociąga za sobą kolejne, dokonane już przez samego herosa: od odmowy wsparcia w konflikcie swoich towarzyszy, mimo wiedzy, że jego bierność przekłada się na setki śmiertelnych ofiar, aż po szaleństwo, w jakie Achilles wpada po śmierci Patroklosa. Miarą nieczłowieczeństwa Achillesa staje się fakt zbezczeszczenia przezeń zwłok trojańskiego bohatera, Hektora. Czyn ten, potępiany zarówno przez bogów, jak i ludzi, stawia Achillesa ostatecznie poza granicami thémis ${ }^{9}$. Grecki heros przekracza granicę człowieczeństwa, co czyni go jednocześnie czymś więcej - półbogiem ważącym się sprzeciwiać rozkazom Olimpu, jak i czymś mniej - bestią nieuznającą cywilizujących ram wspólnoty ${ }^{10}$. Dopiero szczery żal i zadośćuczynienie w formie oddania ciała zabitego Trojanom pozwala Achillesowi odzyskać miano herosa, ponownie umieszczając go w obrębie ludzkiej wspólnoty moralnej. Co ciekawe, Homer ukazuje przemianę Achillesa w dwóch scenach: spotkania z matką, omówionego bardzo skrótowo jako moment przekazania synowi przez Tetydę rozkazu Zeusa, i w rozbudowanej scenie spotkania z Priamem, podczas którego obaj - sędziwy król Troi i grecki wojownik - wspólnie opłakują swoich zmarłych. Iliada jest więc tak naprawdę opisem degeneracji i rehabilitacji greckiego herosa: historią jego upadku, wyjścia poza granice człowieczeństwa, a także jego odkupienia poprzez powrót do moralnej wspólnoty, której granice wyznacza thémis.

Jeżeli spojrzymy na thémis z perspektywy antropologicznej, wyraźnie widać jej porządkujący, dzielący charakter. Thémis albo jest, albo jej nie ma - stany pośrednie nie istnieją. Każdy czyn ma określoną wartość moralną, każdemu zjawisku przypisana jest moralna ocena, podzielana przez społeczność w sposób niekwestionowany

8 Agamemnon również płaci za to wykroczenie wysoką cenę, kończąc ostatecznie z gardłem podciętym przez własną wiarołomną żonę. Patrz: Sofokles, Elektra, przeł. K. Morawski, [online] http:// wolnelektury.pl/katalog/lektura/elektra.html, 27 XI 2017.

9 Jednak, bogowie, wy chcecie Achillesowi dogodzić bezlitosnemu, co w sercu godziwych uczuć ni w piersi myśli roztropnej już nie ma do lwa dzikiego podobny, który potegga zuchwaty i w duszy nieustraszony wpada na wtasność śmiertelnych, by z stada zdobycz pochwycić - tak i Achilles wstyd wszelki i litość w sobie zatracit, wstyd, który ludziom pomaga tak bardzo, a czasem szkodzi. Homer, Iliada, pieśn XXIV, przel. K. Jeżewska, Warszawa 2005. 
i niepodważalny. Wspólnota wartości wyznacza jednocześnie zakres wspólnoty fizycznej. Symbolem tej jednoznaczności jest miecz w dłoni Temidy - wyraziste wizualne przypomnienie konsekwencji i zarazem ostrzeżenie przed transgresją.

Rysunek 2. Okup za Hektora. Hydria czerwonofigurowa (550-510 p.n.e.)

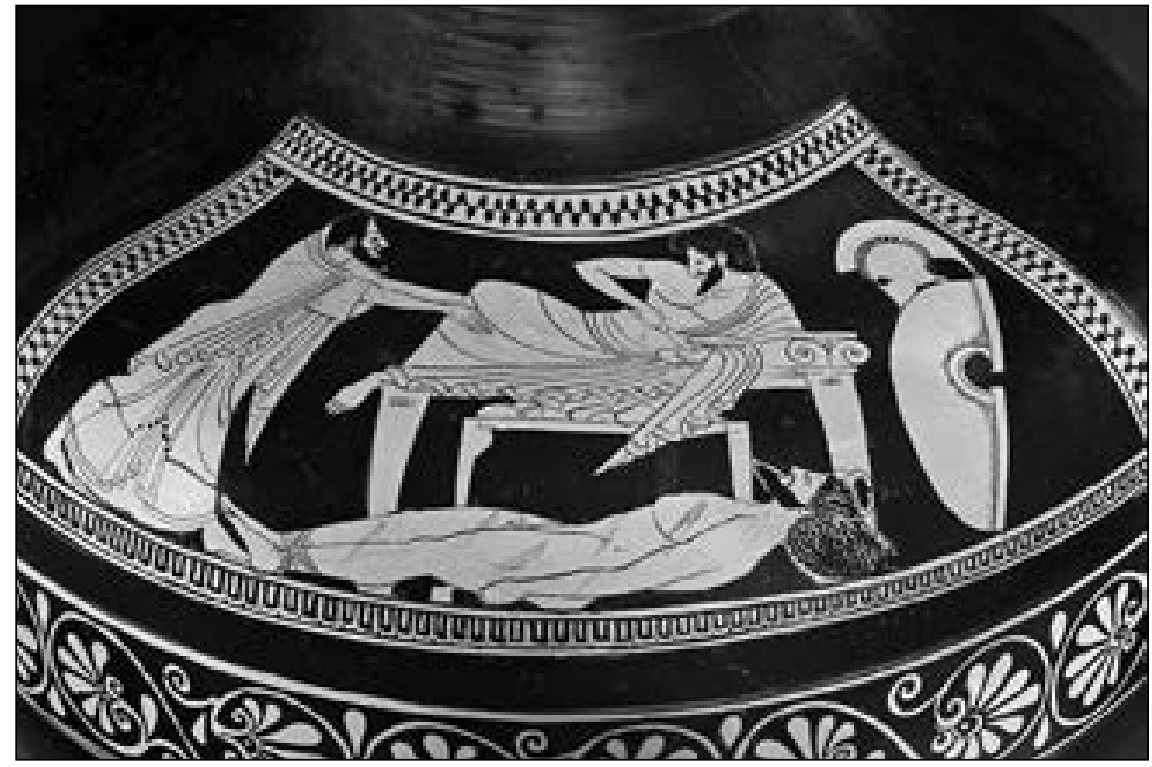

Źródło: (c) Harvard Art Museums

Tworzenie granic jest naturalną ludzką potrzebą. Jak pisze Mary Douglas, gtówna funkcja koncepcji podziatów, oczyszczenia, rozróżniania i karania wykroczeń jest narzucanie beztadnemu z konieczności doświadczeniu charakteru systemowego. Cośn na ksztatt porzadku można osiagnać tylko przesadnie akcentując różnice między tym, co w środku, i tym, co na zewnątrz, w górze i na dole, tym, co z nami, i tym, co przeciw nam ${ }^{11}$.

Granica, czyli linia oddzielająca dwa odrębne zjawiska, stany czy rzeczy ${ }^{12}$, jest podstawowym elementem tego porządku, struktury, systemu znaczeń, jaki człowiek nakłada na otaczającą go płynną rzeczywistość. Człowiek nieustannie tworzy schematy i struktury klasyfikacyjne, wyznaczając granice między poszczególnymi zjawiskami i stanami. Podział rzeczywistości, jej kategoryzacja, ostatecznie umożliwia jej interpretację, nadanie jej sensu. Świat realny pełen jest stanów pośrednich - ale człowiek, kierując się niezgodą na przypadkowość rzeczywistości wyrastającą z potrzeby wiary w celowy ład świata, jak to określił Leszek Kołakowski ${ }^{13}$, stany te usiłuje sprowadzać

11 M. Douglas, Czystość i zmaza, przeł. B. Biały, Warszawa 2007, s. 48.

12 Granica jakiegoś stanu, bytu, pojęcia itp. jest tam, gdzie one się zaczynaja, albo tam, gdzie sie kończa i przestają być soba, stając się czymś innym, [w:] Stownik języka polskiego, red. M. Bańko, Warszawa 2007, t. II, s. 54.

13 L. Kołakowski, Obecność mitu, Warszawa 2009. 
do wspólnych mianowników, de facto dychotomizując realnośćc ${ }^{14}$. Niech wasza mowa będzie: "Tak, tak; nie, nie". A co nadto jest, od Ztego pochodzi (Mt 5,37) ${ }^{15}$. Stany przejściowe, nieokreślone, które nie dają się podporządkować i uporządkować, stanowią wyłom w symbolicznej strukturze nakładanej przez człowieka na rzeczywistość, a zatem stają się zagrożeniem dla tego ładu.

\section{TRICKSTER A THÉMIS - RÓWNOWAŻNOŚĆ FUNKCJONALNA}

Uniwersalność kategorii thémis - a może przede wszystkim ludzkiej potrzeby stojącej za powstaniem thémis - znajduje również potwierdzenie w fakcie istnienia mitologicznych tricksterów. Tam, gdzie thémis nie jest uosobiona czy wyrażana w skonkretyzowanej formie wiecznego niezmiennego prawa, w pokrętny sposób granicę między „tym, co słuszne”, a tym, co niewłaściwe, przedstawiają tricksterzy: mitologiczne uosobienia chaosu, upostaciowione pomieszanie porządków. Tricksterzy są, według Lewisa Hyde'a, „przekraczaczami granic”, „panami świata pomiędzy” ${ }^{16}$. Zwykle przedstawiani jako bogowie, mogą być również półbogami czy mitycznymi herosami - wszystkich jednak łączy niejednoznaczność i aspekt zabawy, charakteryzujący wiele $\mathrm{z}$ ich transgresyjnych poczynań. Aby jednak tricksterzy mogli istnieć i wypełniać swą rolę, potrzebny jest porządek, który mogą łamać, i granice, które mogą przekraczać. Każda transgresja dokonana przez trickstera - a zatem w pewnej mierze dozwolona i zaakceptowana w szerszym porządku rzeczy - wzmacnia istniejącą strukturę, potwierdzając kształt znanego świata właśnie poprzez jego zakwestionowanie. W mitologii greckiej tricksterem, choć w ograniczonym stopniu, jest Hermes, bóg kupców, podróżnych i złodziei - trzech grup niejako skazanych na „bycie pomiędzy”. Hermes jest boskim posłańcem krążącym między Olimpem a ziemią, jest również psychopompem przenoszącym dusze ze świata realnego do duchowego, umożliwiającym komunikację żywych ze światem pozagrobowym. Co ciekawe, za trickstera uchodzić może również Prometeusz - tytan, który dokonał podziału ofiarnego mięsa z korzyścią dla ludzkości i który skradł bogom ogień, by dać go ludziom. Karą za te transgresje było nakazane przez Zeusa cierpienie do końca czasu, codzienna tortura samotności i bólu na szczycie góry. Najbardziej interesujący w micie Prometeusza pozostaje jednak jego rodowód - przynajmniej w części iteracji mitu, u Ajschylosa, jego matką jest nikt inny, jak Temida, utożsamiana z Gaią ${ }^{17}$.

14 Patrz m.in. rozważania Claude’a Lévi Straussa na temat opozycji między naturą i kulturą oraz powiązanego z nią podziału na surowe, smażone i gotowane, a także rozważania Mary Douglas na temat kategorii czystości i brudu. C. Lévi-Strauss, Trójkąt kulinarny, „Twórczość” 1972, nr 2; M. Douglas, Czystość i zmaza, Warszawa 2007.

15 Cytat za: Pismo Święte Starego i Nowego Testamentu w przektadzie zjęzyków oryginalnych, oprac. zespół biblistów polskich z inicjatywy benedyktynów tynieckich, red. A. Jankowski, L. Stachowiak, K. Romaniuk, przeł. W. Borowski i in., Poznań 1980.

16 L. Hyde, Trickster Makes This World: How Disruptive Imagination Creates Culture, Edinburgh 2017.

17 Ajschylos, Prometeusz w okowach, przeł. S. Srebrny, Warszawa 1954. 
Do najsłynniejszych tricksterów należy także Kojot - postać odgrywająca niezwykle istotną rolę w mitologii Indian amerykańskich, oraz bóg-pająk Anansi, pełniący podobną rolę w wierzeniach ludów zachodniej Afryki. W kręgu kultury zachodniej najbardziej znanym tricksterem jest jednak niewątpliwie Loki, nordycki bóg oszustw. Loki, potomek lodowych olbrzymów, brat krwi Odyna, towarzysz Thora, przedstawiany był w nordyckim panteonie na równi z najważniejszymi bóstwami. Był jednak bogiem szczególnym, pozostającym niejako na obrzeżach moralnej i fizycznej wspólnoty asgardzkich bóstw, co wyrażało się nie tylko w oddaleniu jego siedziby od domostw pozostałych bogów, ale przede wszystkim w jego niezwykłej łatwości zmiany kształtu - w różnych mitach bywał mężczyzną, kobietą, klaczą, mgłą, łososiem, ptakiem czy muchą, rodził i płodził bogów i potwory, tworzył wynalazki, a poprzez swoje złośliwe, okrutne żarty równie często sprowadzał gniew i żałobę, co przyczyniał się do poprawy dobrostanu bogów i ludzi ${ }^{18}$. Mimo swych ciągłych psot był jednak nie tylko tolerowany, ale i wysoko ceniony przez pozostałych Asgardczyków. Postać Lokiego perfekcyjnie uosabia podstawową cechę tricksterów: moralną i fizyczną ambiwalencję. On sam staje się niejako strukturą nakładaną na obszar niepewności, zaś wszystkie jego czyny opisywane są z absolutnym przekonaniem, że ostatecznie porządek zostanie przywrócony: zło ukarane, dobro nagrodzone, a wartości moralne danej grupy ponownie potwierdzone. Loki stanowi więc nieusuwalną część nordyckiego świata wierzeń i wartości, swoistą antynomię moralności, która poprzez samo swoje istnienie pozwala na doprecyzowanie granic „tego, co słuszne i właściwe”.

Rysunek 3. Loki obcinający włosy śpiącej Sif

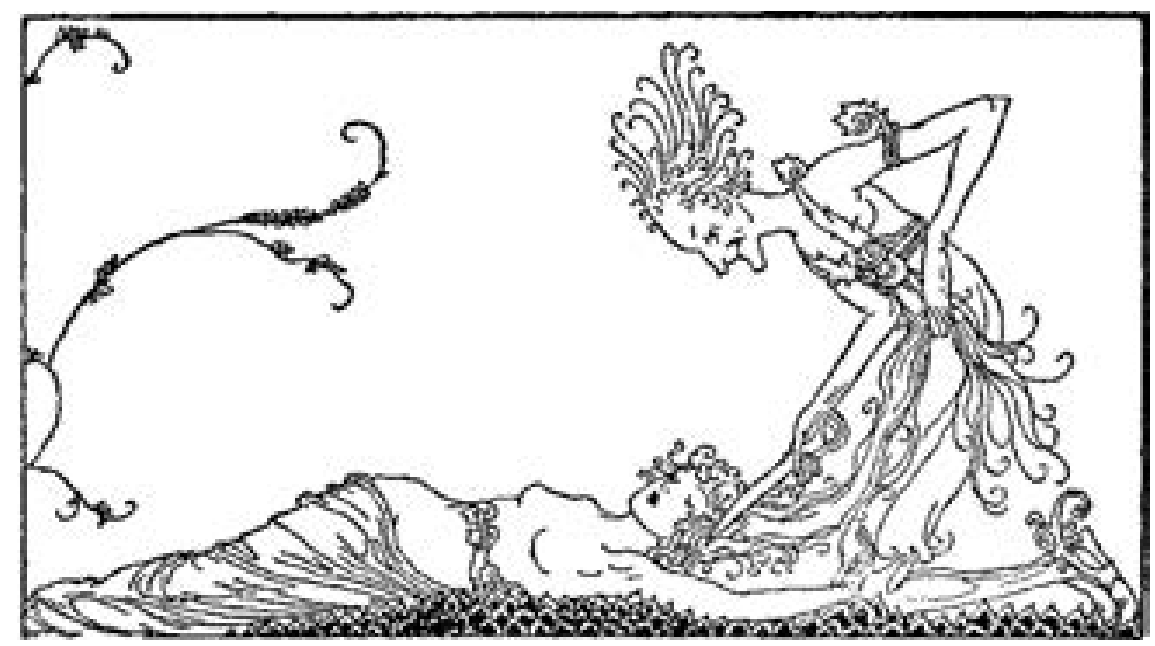

Autor: Willy Pogany

18 Nieco uwspółcześnioną wersję mitów nordyckich spisanych w Eddach można znaleźć w niedawno wydanej Mitologii nordyckiej Neila Gaimana. Patrz: N. Gaiman, Mitologia nordycka, przeł. P. Braiter-Ziemkiewicz, Warszawa 2017. 
Zarówno postać trickstera, jak i idea thémis nie są jednak wyłącznie reliktami przeszłości, artefaktami wierzeń sprzed tysięcy lat. Postać trickstera pełni istotną rolę zarówno w ludowych podaniach (czarty, stworzenia nadprzyrodzone), jak i kanonicznych dziełach literackich. Kiedy Goethe, a za nim Buthakow piszą Jam częścia tej sity, która wiecznie zta pragną, wiecznie dobro czyni ${ }^{19}$, odwołują się właśnie do postaci i roli - trickstera: nieustraszonego kontestatora ustalonego porządku, wielbiciela chaosu, który przekraczając wszelkie granice, tym samym potwierdza ich istnienie.

\section{THÉMIS WSPÓŁCZESNA}

We współczesnym świecie thémis wyrażana jest z kolei w znanej doskonale kategorii „się”, „man kann” czy też „it is/it is not done”. Wszystkie te określenia opisują społeczną sankcję tak potężną, że - przynajmniej w odczuciu społecznym - niepotrzebującą wyjaśnienia. Jako zestaw uniwersalnych, niezmiennych i niepodważalnych praw postępowania thémis stanowi nieodmienny punkt odniesienia, moralną podstawę działań również we współczesnych wspólnotach. Istnienie thémis jest konieczne, aby istnieć mogła intersubiektywność doświadczenia. Thémis jest miejscem spotkania z Levinasowskim Innym. Spotykając Innego, dostrzegamy jego odmienność, wyjątkowość, namacalną konkretność, a zarazem poprzez to spotkanie uzmysławiamy sobie własną osobność bycia w świecie. Jednocześnie Inny jest na tyle podobny do nas samych, że możemy z nim współodczuwać, możemy, a nawet musimy zastosować w odniesieniu do niego własne kategorie moralności; spotykając Innego, otrzymujemy jednocześnie powinność odpowiedzialności. Jak pisze Zygmunt Bauman, analizując fenomenologiczne podejście Emmanuela Levinasa: Końcowa stacją redukcji fenomenologicznej Levinasa okazata się innosśc, nieredukowalna odmienność Innego, która uświadamia wtasnemu ja jego szczególne obowiązki i w ten sposób przyczynia sie, choćby pośrednio, do narodzin subiektywności. U kresu redukcjonistycznego wysitku Levinasa widnieje spotkanie z Innym, wstrzas, który to spotkanie wywotuje, i milczace wotanie Twarzy Innego ${ }^{20}$.

O współczesnej istotności i aktualności thémis świadczy fakt, że to właśnie kategoria „moralnej rany”, naruszenia uniwersalnych, podstawowych zasad ludzkiego współbycia jest powszechnie wykorzystywana jako czynnik wyjaśniający traumę bojową $\mathrm{u}$ amerykańskich żołnierzy po wojnach w Wietnamie, Iraku i Afganistanie. Thémis w obręb współczesnych nauk społecznych została wprowadzona przez Jonathana Shaya, amerykańskiego psychiatrę leczącego PTSD u weteranów wojny w Wietnamie, autora książek Achilles in Vietnam: Combat Trauma and the Undoing of Character (1994) oraz Odysseus in America: Combat Trauma and the Trials of Homecoming (2002). Poszukując podobieństw między antyczną okupacją miasta-państwa

19 Ich bin ein Teil von jener Kraft, die stets das Böse will und stets das Gute schafft. J.W. von Goethe, Faust, przeł. F. Konopka, Warszawa 1977. Cytat ten stanowi również motto powieści Michaiła Bułhakowa Mistrz i Matgorzata. Patrz: M. Bułhakow, Mistrz i Matgorzata, przeł. I. Lewandowska, W. Dąbrowski, Kraków 2004. 
a współczesnym, uprzemysłowionym konfliktem zbrojnym na wielką skalę, Shay doszedł do wniosku, że obie - pozornie niezmiernie różniące się od siebie - wojny charakteryzowało naruszenie thémis: ogólnej kulturowej definicji tego, co słuszne i właściwe, zawierającej w sobie takie zjawiska, jak porządek moralny, społeczne przekonania, normatywne oczekiwania, etykę oraz podzielane wartości ${ }^{21}$. Według amerykańskiego psychiatry to ten właśnie czynnik odpowiedzialny jest w dużej mierze za rozwój traumy bojowej. Niewątpliwie poczucie krzywdy i alienacji charakteryzuje współcześnie bardzo wielu amerykańskich weteranów. Współcześni żołnierze biorący udział w konfliktach zbrojnych tak samo jak wojownicy ze starożytnej Grecji stają się częścią szczególnej wspólnoty wojennej - braterstwa broni. Od tej niewielkiej grupy ludzi, świadków i uczestników wojennych wydarzeń, w których bierze udział żołnierz, zależy jego biologiczne i psychologiczne przetrwanie. Grupa ta staje się niejako nową „rodziną” żołnierza, zbiorem nowych „znaczących innych" w ujęciu interakcjonizmu symbolicznego ${ }^{22}$. Niezależnie zatem od epoki historycznej, pola bitwy czy używanej broni, etos żołnierski musi opierać się na nienaruszalności podstawowych zasad rządzących światem wojny. Kiedy więc ta wspólnota wartości ulega naruszeniu, thémis zostaje zastąpiona przez mênis - poczucie bycia zdradzonym, upokorzenie oraz wściekłośćc ${ }^{23}$.

\section{FORMY NARUSZENIA THÉMIS}

Te negatywne emocje pełnią niezwykle istotną rolę w kształtowaniu się u jednostki PTSD - syndromu stresu posttraumatycznego, będacego rezultatem uczestnictwa w niezwykle stresujacym, przerażającym lub katastroficznym wydarzeniu, w czasie którego fizyczna nietykalnośćjednostki zostata - lub mogta zostać - naruszon $a^{24}$. Wojna jako zjawisko znajdujące się w całkowitej opozycji wobec świata życia codziennego posiada jeden z najwyższych potencjałów traumatogennych ${ }^{25}$. Kiedy koszmarowi wojny towarzyszy naruszenie thémis, rozwój PTSD u tak doświadczonej jednostki jest według Shaya niemal nie do uniknięcia.

Możliwe są dwa podstawowe scenariusze naruszenia thémis w sytuacji wojennej pierwszy znany nam już z historii Achillesa, kiedy Agamemnon, dowódca greckich wojsk, należący razem z Achillesem do elitarnego braterstwa broni, łamie uświęcone zasady, powodując alienację i szaleństwo herosa. Drugi zaś scenariusz, opisany według Shaya w Homerowskiej Odysei ${ }^{26}$, przedstawia naruszenie thémis, do którego dochodzi

21 J. Shay, Achilles in Vietnam. Combat Trauma and the Undoing of Character, New York 2003, s. 5.

22 Patrz m.in.: G.H. Mead, Umyst, osobowość, spoteczeństwo, przeł. Z. Wolińska, Warszawa 1975, H. Blumer, Interakcjonizm symboliczny. Perspektywa i metoda, przeł. G. Woroniecka, Kraków 2008.

23 J. Shay, Achilles in Vietnam..., s. 19.

24 A. Gruszczyk, Czarne światto. Analiza zjawiska powojennej traumy spotecznej w kulturze Stanów Zjednoczonych Ameryki, Kraków 2017, s. 59.

25 Szersze omówienie tej problematyki znajduje się w mojej książce $C z a r n e$ światto.

26 Homer, Odyseja.... 
w świecie życia codziennego - już po wojnie, na rodzinnej ziemi, kiedy każdy weteran oczekuje powrotu do normalności i ponownego włączenia się do szerokiej wspólnoty społecznej, z której się wywodzi. Homerowska Odyseja stanowi kronikę powrotnej podróży do domu Odyseusza, weterana wojennego spod Troi. Wojna trojańska trwała całą dekadę: dziesięć długich lat krwawych bitew i trudnych konfliktów wewnętrznych, niewygód, poczucia tymczasowości, oddzielenia od bliskich, szaleństwa i śmierci. Powrót na rodzinną Itakę zajmuje greckiemu herosowi kolejne dziesięć lat - znacznie dłużej niż któremukolwiek innemu bohaterowi spod Troi. Kiedy zaś wreszcie Odys przybywa na wyspę, dowiaduje się, że jego dom oblegany jest przez wrogo doń nastawionych mężczyzn, dążących do przejęcia jego żony, jego majątku i jego władzy. U Homera przygody Odyseusza mają niezwykły, niemal bajkowy charakter - grecki heros trafia na wyspę krwiożerczych Cyklopów, zmaga się ze Scyllą i Charybdą, czarodziejką Kirke i buntem załogi, a we wszystkich swoich przedsięwzięciach jest wspierany lub zwalczany przez skłóconych olimpijskich bogów. Zmęczony, przedwcześnie postarzały, pragnący tylko powrotu do normalności Odys we własnym domu staje przed najtrudniejszą próbą zmierzenia się z wrogością świata, który traktował dotąd jako oczywiste, naturalne, należne sobie miejsce życia. Odyseja kończy się niezwykle brutalnie i krwawo właśnie dlatego, że opisuje konsekwencje drastycznego naruszenia thémis. Bezwzględny mord na zalotnikach Penelopy w eposie Homera uzyskuje sankcję czynu wręcz bohaterskiego, niczym kolejna z mitycznych prób, którym zwykle poddawani są greccy herosi. Odyseusz do samego końca otrzymuje wsparcie od Ateny, greckiej bogini mądrości i wojny, razem z nią układając plany odzyskania domu i władzy. A gdy wreszcie krwawa waśń się kończy, społeczność Itaki nie domaga się sprawiedliwości na mordercy synów potężnych rodów nie tylko dlatego, że Odyseusz jest ich prawowitym władcą. Zalotnicy Penelopy zostali wszak wykluczeni z thémis - a wręcz sami się wykluczyli, łamiąc zasady gościnności, honoru i odpowiedzialności. To ta transgresja ostatecznie powoduje, że prawa wspólnoty przestają ich dotyczyć.

\section{OBRAZY ZDRADY THÉMIS WE WSPÓŁCZESNEJ KULTURZE}

Podobną opowieść przedstawia również najnowszy serial Netflixa, oparty na serii komiksów Marvela The Punisher ${ }^{27}$. Tytułowy Punisher to weteran wojenny, powracający do Nowego Jorku po latach walk w Afganistanie i Iraku. Świetnie wyszkolony i brutalnie doświadczony wojną żołnierz, przekonany, że wypełnił już obowiązek wobec ojczyzny, wraca do rodziny - tylko po to, by stać się świadkiem zabójstwa swojej żony i dzieci przez członków mafii organizujących w miejskim parku egzekucję świadka. Utrata jedynego stałego punktu odniesienia, który pomógł mu przetrwać chaos wojny - rodziny, uruchamia błędne koło desperacji, alienacji i traumy. Frank Castle

27 G. Conway, J. Romita Sr., R. Andru, The Punisher, Marvel, od 1974. Serial Netflixa stworzony zostal przez Steve’a Lightfoota i wyreżyserowany przez 11 reżyserów, z których każdy odpowiedzialny był za inny odcinek (z wyjątkiem Toma Shanklanda i Andy'ego Goddarda, którzy wyreżyserowali po dwa odcinki). 
uzmysławia sobie, że podstawowe założenia, na jakich opierał swoją egzystencję, zostały zakwestionowane. Tym samym jego dotychczasowy Lebenswelt ulega nieodwracalnemu zniszczeniu. Ojczyzna, której przez tyle lat służył, w rzeczywistości okazuje się mrzonką, nieistniejącym ideałem. W czasie, kiedy Castle przelewał krew za swój kraj, ten stał się ziemią obiecaną przestępców, zabijających niewinnych ludzi w biały dzień. Wartości wspólnoty, dla których bohater był gotów poświęcić życie, są odrzucane przez samą tę wspólnotę, biernie przyzwalającą na działalność rabusiów, morderców i złodziei.

Temu odyseuszowemu z natury naruszeniu thémis towarzyszy drugie, achillesowe, kiedy wychodzi na jaw, że rodzina Castle’a została zabita na polecenie jego dawnych towarzyszy broni, próbujących ukryć własne, popełnione na wojnie zbrodnie. Żołnierskie braterstwo krwi, ta „druga rodzina” Franka, okazuje się pustym sloganem, mirażem służącym do zamaskowania brutalnej rzeczywistości, w której pieniądze i obietnica wygodnego życia okazują się ważniejsze od międzyludzkich więzi czy jakichkolwiek wartości. Castle już wcześniej przeżywa kryzys wiary w siebie oraz otaczający go świat, wynikający z faktu, że w czasie wojny zmuszony był do wykonywania rozkazów, których moralność i zasadność kwestionował. Wynikające z tego pęknięcie thémis, poczucie bycia zdradzonym i wykorzystanym przez przełożonych, stanowi jednak jedynie pierwszy etap zniszczenia wspólnoty moralnej. Thémis tej wspólnoty ostatecznie przestaje istnieć w wyniku jej zdrady przez samych członków grupy społecznej, na istnieniu której Castle opierał swoje bycie w świecie. Podobnie jak Achilles, Castle na zdradę thémis reaguje wściekłością i szałem przemocy, dobrowolnym wykluczeniem ze swojej wspólnoty. Podobnie jak Odyseusz, nakładający maski, przebierający się za żebraka we własnym domu, aby dokonać zemsty na zdrajcach thémis, również Frank Castle przywdziewa kostium, zmieniając się w Punishera - zamaskowanego mściciela, mordującego z zimną krwią swoich współobywateli, którzy wykroczyli przeciwko ideałowi „tego, co słuszne”. Naruszenie thémis ma wyjątkowo dalekosiężne konsekwencje: Castle wprowadza w świat życia codziennego rzeczywistość wojny, zamazując czy wręcz aktywnie niszcząc granice między nimi. W akcie zniszczenia thémis przestaje istnieć jakakolwiek wspólnota moralna czy fizyczna - Punisher świadomie staje się wyrzutkiem społecznym, w akcie całkowitej alienacji odrzucając swoje dotychczasowe miejsce w strukturze społecznej, dawne więzi i obligacje, a nawet własne imię. Jedynym stałym punktem jego egzystencji staje się wyznawana przez niego hierarchia wartości oraz wszechogarniająca mênis - słuszny gniew zrodzony z poczucia zdrady ${ }^{28}$. Mênis Punishera to gniew wojownika, wyrastający ze zdrady thémis opartej na ideałach honoru, lojalności i braterstwa wojny. I tak jak reakcja Odyseusza na zdradę thémis w jego rodzinnej wspólnocie przywołuje w nim nie pokojowo nastawionego władcę Itaki, lecz brutalnego mordercę spod Troi, tak i Frank Castle w swoim wcieleniu zamaskowanego mściciela opiera się na wojennych zasadach: przemocy i zemsty.

28 Należy tu podkreślić, że mênis nie jest przeciwieństwem thémis, lecz reakcją na jej naruszenie; jako kategoria słusznego gniewu mênis może być interpretowana jako niezwykle gwałtowna i agresywna bo odpowiadająca wadze wykroczenia - próba przywrócenia ciągłości i nienaruszalności thémis. 
Rysunek 4. Plakat promujący serial Netflixa, Marvel's The Punisher

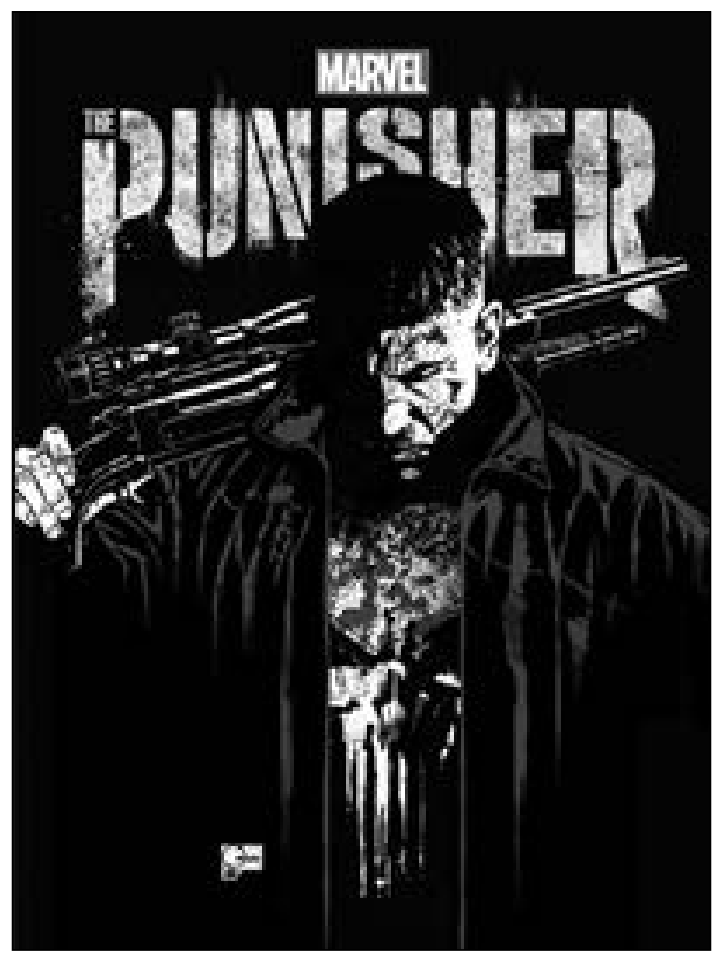

(C) Netflix

Castle w przeciwieństwie do większości zamaskowanych bohaterów nie ukrywa swojej „cywilnej” tożsamości ani jej nie nagłaśnia - raczej ją „nadpisuje”, pozwalając, by na pierwszy plan wychodziła przyjęta przezeń rola mściciela, wyrażona w jego przebraniu. Charakterystyczną cechą kostiumu Punishera jest biała trupia czaszka na czarnym tle. Służy ona podwójnemu celowi: z jednej strony ma wywoływać strach u jego przeciwników poprzez przywołanie antycznej idei memento mori, z drugiej zaś oznacza samego Punishera jako istotę „naznaczoną śmiercią”, przekraczającą ramy podziału na święte i świeckie. Punisher dla swoich wrogów wręcz staje się śmiercią: w przeciwieństwie do ślepej Temidy istotą wszystkowidzącą i wszechobecną, niespętaną zasadami wspólnotowej moralności, emocji czy nawet interpersonalnych więzi.

\section{THÉMIS WSPÓŁCZESNA}

Marvelowski Punisher jest mroczną, brutalną fantazją, ale i niepokojąco dokładnym odbiciem rzeczywistości. Amerykańska historia i kultura pełne są opowieści o byłych żołnierzach, rozgoryczonych, sfrustrowanych, biorących sprawiedliwość we własne ręce w poczuciu, że wspólnota ich zawiodła. Masked vigilante, zamaskowany samozwańczy 
strażnik prawa, jest jednym z najistotniejszych wzorców amerykańskiej kultury popularnej i bezpośrednim następcą samotnych mścicieli, wymierzających sprawiedliwość na Dzikim Zachodzie. Od westernowych bohaterów granych przez Johna Wayne’a poprzez Batmana (który nieprzypadkowo nosi to samo nazwisko co aktor wcielający się w najsłynniejszych szeryfów Dzikiego Zachodu) i Rorschacha aż po Punishera, amerykańska kultura wypełniona jest ambiwalentnymi postaciami znajdującymi się poza granicą wspólnotowej thémis. Amerykańskie społeczeństwo wydaje się zafascynowane heroicznym, pozaludzkim statusem tych postaci, a mit samotnego mściciela krzywd przenika do życia codziennego. Wymyślona historia cierpiącego na PTSD weterana wojny w Wietnamie, Johna Rambo ${ }^{29}$, który po powrocie do kraju, sprowokowany pogardą, wykluczeniem i prześladowaniami ze strony lokalnej społeczności, zaczyna toczyć z przedstawicielami prawa własną, prywatną wojnę, została urealniona w historii Benjamina Coltona Barnesa, weterana wojny w Iraku, który w styczniu 2012 roku po strzelaninie na noworocznej imprezie uciekł do parku narodowego, zastrzelił strażniczkę i przez kilka dni, aż do śmierci z wychłodzenia, ukrywał się przed około 200 policjantami, agentami federalnymi i strażnikami leśnymi ${ }^{30}$. Ten destrukcyjny proces naruszenia thémis i późniejszych konsekwencji tak postrzeganej zdrady wpleciony jest w amerykańską historię co najmniej od dziesiątek, jeśli nie od setek lat. Analiza zarówno zawartości thémis w danej wspólnocie, jak i przypadków jej zdrady ma znaczącą moc eksplikacyjną. Naruszenie thémis łączy bowiem tak różne sprawy, jak zabójstwo prezydenta Johna F. Kennedy'ego w 1963 roku przez Lee Harveya Oswalda ${ }^{31}$, przypadek Itzcoatla Ocampo, który na ulicach Orange County w Kalifornii w latach 2012-2013 zabijał bezdomnych, ponieważ w jego przekonaniu byli „pomorem”, „śmieciami do usunięcia”32, oraz tortury w irackim Abu Ghraib, jakich amerykańscy żołnierze dopuszczali się na więźniach w latach 2003-2004 ${ }^{33}$.

Thémis jednak istnieje przede wszystkim w formie pozytywnej - jako „to, co słuszne”, „to, co właściwe”. Jest to obszar wspólnoty wartości, zarówno tych wyartykułowanych, wynegocjowanych w procesie społecznej komunikacji, jak i tych przyjmowanych za oczywiste i niezmienne, dane raz na zawsze w świecie życia codziennego. To thémis

29 John Rambo jest bohaterem powieści Davida Morrella First Blood z 1972 r., a także główną postacią w serii wojenno-sensacyjnych filmów, jednak tu odnoszę się wyłącznie do pierwszego z nich, ekranizacji powieści Morrella, również zatytułowanej First Blood. D. Morrell, First Blood, New York 2000, oraz T. Kotcheff, First Blood, Rambo: Pierwsza krew, 1982.

30 L. R. Myers, Benjamin Colton Barnes, Mount Rainier Gunman, Died Of Drowning, Hypothermia, „Huffington Post”, 4 I 2012, [online] https://www.huffingtonpost.com/2012/01/04/benjamin-colton-barnes_n_1182636.html, 1 XII 2017.

31 O militarnej przeszłości Oswalda można w skrócie przeczytać w artykule dostępnym na angielskojęzycznej Wikipedii: [online] https://en.wikipedia.org/wiki/Lee_Harvey_Oswald, 1 XII 2017.

32 I. Lovett, Veteran Charged in Slayings of Four Homeless Men, „The New York Times”, 17 I 2012, [online] http://www.nytimes.com/2012/01/18/us/veteran-charged-in-slayings-of-california-homeless.html, 4 XII 2017.

33 S.M. Hersh, Torture at Abu Ghraib, „The New Yorker”, 10 V 2004, [online] https://www.newyorker. com/magazine/2004/05/10/torture-at-abu-ghraib, 4 XII 2017. 
- a raczej napięcie między jej istnieniem a nieistnieniem, cienka granica jej występowania - wyznacza ramy naszego człowieczeństwa rozumianego jako egzystencja znacząca, obdarzona sensem, oparta na współbyciu z innymi. Reakcją na naruszenie thémis w kulturze greckiej była mênis - jednostkowy, wszechogarniający gniew, ale zarazem wyraz kosmicznej sankcji przeciwko zdradzie wspólnych wartości ${ }^{34}$. Homerycka Iliada jest wszak opisem gniewu Achillesa, drobiazgowym przywołaniem konsekwencji zdrady thémis. Natomiast brakiem thémis, ab-thémis, można nazwać zjawisko opisane i nazwane przez Émile’a Durkheima - anomię ${ }^{35}$. Najkrócej rzecz ujmując, anomia to stan chaosu normatywnego, pojawiający się zazwyczaj w wyniku radykalnych społecznych przemian i prowadzący do rozpadu więzi społecznych, poczucia jednostkowego osamotnienia i bezradności. Używając zatem kategorii pojęciowych stosowanych przez starożytnych Greków, anomia opisuje po prostu proces obumierania thémis: rozmycie i zanik dotychczasowych struktur i wartości rządzących danym społeczeństwem, stan, w którym dana wspólnota wartości - a z nią i wspólnota jednostek - przestaje istnieć.

Granice thémis rozumianej jako ogólnoludzka wspólnota wartości zmieniały się wielokrotnie w ciągu dziejów wraz z poszerzaniem się granic zawartości terminu „człowiek”. W przemiany te wpisuje się zarówno słynny spór pomiędzy Bartolomé de Las Casas a Juanem Ginésem de Sepúlvedą, przeprowadzony w Valladolid w dobie konkwisty, dotyczący kwestii posiadania lub braku dusz u Indian południowoamerykańskich $^{36}$, jak i ustanowienie przez Zgromadzenie Ogólne ONZ Powszechnej Deklaracji Praw Człowieka w 1948 roku $^{37}$, w trzy lata po zakończeniu jednego z najkrwawszych konfliktów w historii. Jeśli więc mówimy dziś o przyrodzonych prawach człowieka, wyrastających z pojęcia niezbywalnej godności ludzkiej i odnoszących się do idei wolności, równości i braterstwa, mówimy w gruncie rzeczy o zuniwersalizowanej thémis, włączającej wszystkie podobne nam istoty w obręb naszej wspólnoty wartości ${ }^{38}$. Oczywiście, wiele zależy od naszej definicji podobieństwa, od umiejętności dostrzeżenia i chęci zrozumienia Innego nawet w postaci tych, z którymi komunikacja jest pozornie niemożliwa. I w tym kontekście powinniśmy zadać sobie pytanie o nasze traktowanie Innego, kimkolwiek by nie był: uchodźcą, samotnym weteranem czy zwierzęciem.

\section{Muellner, The Anger of Achilles. Mênis in Greek Epic, Ithaca 1996.}

35 W znanej rozprawie Samobójstwo. Studium z socjologii Durkheim powiązał wzrost liczby samobójstw z rozpadem więzi społecznych, będącym wynikiem chaosu normatywnego. Patrz: É. Durkheim, Samobójstwo. Studium z socjologii, przeł. K. Wakar, Warszawa 2011.

36 W. Jacórzyński, M. Krysińska-Kałużna, Spór o Innego w XVI wieku: Indianie i konkwistadorzy, „Etyka”, 2001, nr 34.

37 Pełny tekst deklaracji dostępny jest m.in. na polskiej stronie UNIC: http://www.unic.un.org.pl/ prawa_czlowieka/dok_powszechna_deklaracja.php, 4 XII 2017, http://www.unic.un.org.pl/doku menty/deklaracja.php, 19 V 2019.

38 Coraz częściej mówi się również dziś o idei praw roślin jako istot czujących i myślących. Patrz: S. Mancuso, A. Viola, Brilliant Green: The Surprising History and Science of Plant Intelligence, Washington 2015, oraz J. Hance, Are Plants Intelligent? New Book Says Yes, „The Guardian”, 4 VIII 2015, [online] https://www.theguardian.com/environment/radical-conservation/2015/aug/04/ plants-intelligent-sentient-book-brilliant-green-internet, 12 I 2017. 


\section{BIBLIOGRAFIA}

Ajschylos, Agamemnon, przet. H.W. Smyth, Cambridge, MA 1926.

Ajschylos, Prometeusz w okowach, przet. S. Srebrny, Warszawa 1954.

Bauman Z., Szanse etyki w zglobalizowanym świecie, przeł. J. Konieczny, Kraków 2007.

Blumer H., Interakcjonizm symboliczny. Perspektywa i metoda, przeł. G. Woroniecka, Kraków 2008.

Bułhakow M., Mistrz i Matgorzata, przel. I. Lewandowska, W. Dąbrowski, Kraków 2004.

Conway G., Romita J. Sr., Andru R., The Punisher, Marvel, 1974 - dziś.

Douglas M., Czystość i zmaza, przeł. B. Biały, Warszawa 2007.

Durkheim É., Samobójstwo. Studium z socjologii, przeł. K. Wakar, Warszawa 2011.

Finley M., The World of Odysseus, New York 2002.

Gaiman N., Mitologia nordycka, przeł. P. Braiter, Warszawa 2017.

Goethe J.W., Faust, przeł. F. Konopka, Warszawa 1977.

Gruszczyk A., Czarne światto. Analiza zjawiska powojennej traumy spotecznej w kulturze Stanów Zjednoczonych Ameryki, Kraków 2017.

Hance J., Are Plants Intelligent? New Book Says Yes, „The Guardian”, 4 VIII 2015, [online] https://www.theguardian.com/environment/radical-conservation/2015/aug/04/plants-intelligent-sentient-book-brilliant-green-internet, 12 I 2017.

Hersh S.M., Torture at Abu Ghraib. „The New Yorker”, 10 V 2004, [online] https://www.newyorker.com/magazine/2004/05/10/torture-at-abu-ghraib, 4 XII 2017.

Hezjod, Teogonia, przeł. K. Kaszewski, Warszawa 2005.

Homer, Iliada, przel. F.K. Dmochowski, [online] https://wolnelektury.pl/katalog/lektura/ homer-iliada.html, 27 XI 2017.

Homer, Iliada, przel. K. Jeżewska, Warszawa 2005.

Homer, Odyseja, przeł. L. Siemieński, [online] https://wolnelektury.pl/katalog/lektura/homer-odyseja.html, 09 I 2018.

Hyde L., Trickster Makes This World: How Disruptive Imagination Creates Culture, Edinburgh 2017.

Jacórzyński W., Krysińska-Kałużna M., Spór o Innego w XVI wieku: Indianie i konkwistadorzy, „Etyka”, 2001, nr 34.

Kołakowski L., Obecność mitu, Warszawa 2009.

Kotcheff T., First Blood. Rambo: Pierwsza krew, 1982.

Lee Harvey Oswald, https://en.wikipedia.org/wiki/Lee_Harvey_Oswald, 1 XII 2017.Lévi-Strauss C., Trójkąt kulinarny, przeł. S. Ciechowicz, „Twórczość” 1972, nr 2.

Lightfoot S., Marvel's The Punisher, Netflix, 2017.

Lovett I., Veteran Charged in Slayings of Four Homeless Men. „The New York Times”, 17 I 2012, [online] http://www.nytimes.com/2012/01/18/us/veteran-charged-in-slayings-of-california-homeless.html, 04 XII 2017.

Mancuso S., Viola A., Brilliant Green: The Surprising History and Science of Plant Intelligence, Washington 2015.

Mead G.H., Umyst, osobowość, spoteczeństwo, przet. Z. Wolińska, Warszawa 1975.

Morrell D., First Blood, New York 2000. 
Muellner L., The Anger of Achilles. Mênis in Greek Epic, Ithaca 1996.

Myers L.R., Benjamin Colton Barnes, Mount Rainier Gunman, Died Of Drowning, Hypothermia, „Huffington Post”, 4 I 2012, [online] https://www.huffingtonpost.com/2012/01/04/ benjamin-colton-barnes_n_1182636.html, 1 XII 2017.

Pismo Święte Starego i Nowego Testamentu w przektadzie z jezyków oryginalnych, oprac. zespół biblistów polskich z inicjatywy benedyktynów tynieckich, red. A. Jankowski, L. Stachowiak, K. Romaniuk, przeł. W. Borowski i in., Poznań 1980.

Powszechna Deklaracja Praw Człowieka, Organizacja Narodów Zjednoczonych, [online] http://www.unic.un.org.pl/prawa_czlowieka/dok_powszechna_deklaracja.php, 4 XII 2017, http://www.unic.un.org.pl/dokumenty/deklaracja.php, 19 V 2019.

Radwan-Pragłowski J., Kobieta i mężczyzna. Człowiek rozdwojony, Kraków 2009.

Schütz A., O wielości światów, przeł. B. Jabłońska, Kraków 2008.

Shay J., Achilles in Vietnam. Combat Trauma and the Undoing of Character, New York 2003.

Stownik jezzkk polskiego, red. M. Bańko, Warszawa 2007.

Sofokles, Elektra, przeł. K. Morawski, [online] http://wolnelektury.pl/katalog/lektura/elektra. html, 27 XI 2017.

Dr Aleksandra GRUSZCZYK - absolwentka studiów socjologicznych na Uniwersytecie Jagiellońskim, wykładowca UJ. Autorka książek: Bezpieczeństwo za cenę wolności, analizującej zachowania wyborcze Polaków po 1989 roku, i Czarne światto. Analiza zjawiska powojennej traumy spotecznej w kulturze Stanów Zjednoczonych Ameryki, a także wielu artykułów poświęconych m.in. zagadnieniom powojennej traumy społecznej, dylematom wolności i bezpieczeństwa oraz kwestii bezpieczeństwa państwa. 